DOI 10.30740/jee.v1i1p13-20.2

\title{
THE EFFICIENCY OF USING EDUCATION VIDEOS ON THE LINEAR PROGRAM MATERIAL AS OBSERVED IN VOCATIONAL HIGH SCHOOL STUDENTS' MATHEMATICAL COMMUNICATION ABILITY
}

\author{
Laela Zakiah ${ }^{1}$, Asy Syifa Nurul Saomi ${ }^{2}$, Rita Syara ${ }^{3}$, Wahyu Hidayat ${ }^{4}$, Heris Hendriana ${ }^{5}$ \\ ${ }^{1}$ Laela Zakiah, SMK AL-Halim Garut, Garut Indonesia \\ ${ }^{2}$ Asy Syifa Nurul Saomi, SMA Plus Asshofaa Al-Qodiri, Kabupaten Bandung, Indonesia \\ ${ }^{3}$ Rita Syara, SMP 4 Purwakarta, Purwakarta Indonesia \\ ${ }^{4,5}$ IKIP Siliwangi, Cimahi, West Java, Indonesia \\ 1'laelazakiah94@gmail.com, 2asysyifans21@gmail.com, ${ }^{3}$ syararita04@gmail.com, \\ ${ }^{4}$ wahyu@ikipsiliwangi.ac.id, ${ }^{5}$ herishen@ikipsiliwangi.ac.id
}

Received: Desember 15, 2017; Accepted: January 5, 2018

\begin{abstract}
This research has a purpose to find out the efficiency of of using education videos to increase the vocational high school students' mathematical communication ability. The method used for this research was a quasi experiment method where the researcher took two classes as research samples. The first class was the experimental class where the students were shown the education videos and the second class was the control class where the students were taught as usual. The materials which were used for this research was a linear program. The research's populations were the tenth grade students of SMK AL-Halim Garut with class X Multimedia and X Teknik Komputer dan Jaringan (TKJ) (Class of Computer Techniques and Network) as the samples. From the result of the first normality data analysis test (Pre-test), it was found that the experimental class did not distribute normally, therefore, the research continued by using Mann Whitney's experiment. Sig. $0.456 \geq 0.05$ was resulted from the count, therefore $\mathrm{H}_{0}$ was accepted, it meant that there was no difference between the experimental class and control class. Meanwhile, on the final test (Post-test), the scores of both classes did not distribute normally, therefore Mann Whitney's experiment was used again to find out. Sig. $0.000 \geq 0.05$ was resulted from the count, therefore $\mathrm{H}_{0}$ was rejected. In conclusion, "The efficiency of the students' mathematical communication ability who got the education videos was more effective than those who were taught as usual on the linear program material"
\end{abstract}

Keywords: education videos, mathematical communication ability, linear program

\begin{abstract}
Abstrak
Penelitian ini bertujuan untuk mengetahui efektivitas penggunaan video pembelajaran untuk meningkatkan kemampuan komunikasi matematik siswa SMK. Metode penelitian ini adalah kuasi eksperimen, dimana peneliti mengambil dua kelas sebagai sampel penelitan, yaitu kelas pertama sebagai kelas eksperimen mendapatkan video pembelajaran dan kelas kedua sebagai kelas kontrol mendapatkan pembelajaran biasa. Materi yang digunakan dalam penelitian ini adalah program linear. Populasi pada penelitian ini adalah seluruh siswa kelas X SMK AL-HALIM Garut dengan sampel kelas yang dipilih yaitu X Multimedia dan X Teknik computer dan jaringan (TKJ). Dari hasil uji normalitas analisis data tes awal (Pretest), diperoleh bahwa skor tes awal pada kelompok eksperimen tidak berdistribusi normal, maka pengujiannya dilanjutkan dengan uji Mann Whitney, Dari perhitungan diperoleh nilai sig. $0.456 \geq 0.05$ maka $\mathrm{H}_{0}$ diterima, artinya kelas eksperimen dan kelas
\end{abstract}


12 Zakiah, Saomi, Syara, Hidayat, Hendriana. (2018). The Efficiency Of Using Education Videos On The Linear Program Material As Observed In Vocational High School Students' Mathematical Communication Ability. JEE, 1 (1), 11 - 18.

kontrol tidak terdapat perbedaan. Sedangkan pada tes akhir (Posttest) diperoleh skor kedua kelompok tidak berdistribusi normal, maka pengujiannya dilanjutkan dengan uji Mann Whitney. Dari perhitungan diperoleh sig. $0.000<0.05$ maka $\mathrm{H}_{0}$ ditolak. Jadi dapat disimpulkan bahwa "Efektivitas kemampuan komunikasi matematik siswa yang memperoleh video pembelajaran lebih efektif daripada siswa yang memperoleh pembelajaran biasa pada materi program linear"

Kata Kunci: video pembelajaran, kemampuan komunikasi matematik, program linear.

How ti cite : Zakiah, Laela., Saomi, Asysyifa Nurul., Syara, Rita. (2017). The Efficiency Of Using Education Videos On The Linear Program Material As Observed In Vocational High School Students' Mathematical Communication Ability. JEE, 1 (1), 11 - 18.

\section{INTRODUCTION}

According to Shadiq (Ramellan, Musdi E, Armiati, 2012), mathematics has the role as a symbolic language which has the possibility to create the smart and exact communication. Mathematics is not only the aid to think but also the media of communication between student with student and teacher with student. All people are expected to use mathematical language to communicate information or ideas. Many problems are delivered in mathematical language, for example, delivering the problem into mathematics model such as diagrams, mathematics equations, graphics, and tables. Communicating ideas with mathematical language will be more practical, systematic, and efficient. Every student needs to learn mathematics because mathematics is a strong, systematic, and exact communication aid. Mathematics is closely related to our daily lives. Communicating can help the students to increase their vocabulary, expanding their speaking ability, writing systematic ideas, and having better studying ability.

Looking at the result of the research, the students of SMK AL-Halim Garut had a low mathematical grade especially on the mathematical communication ability that it motivated to do the research in order to solve the problem.

In students' daily lives while studying at school, the fact that their mathematical communication ability was not at its best could be seen, e.g. 1) The students were not able to restate a concept and understanding with the terms; 2) The students still found it difficult to classify the objects according to specific features from a concept upon a problem; 3) The students lacked at identifying adequate amount of data to do a problem solving; 4) The students were still not able to make a mathematics model from a situation or daily problems (in real world); 5) The students were still not able to choose and apply the strategy to solve a mathematics problem; 6) The students were still not able to explain or interpret the result according to the original problem, they were also not able to examine the result validity or the result they got. It probably happened because of their study activity which was still not efficient (Febrinal, 2016).

That problem can be caused by the wrong study method, the class' atmosphere, incomplete textbooks and materials and also other education media. It therefore impacts the students' study results which are not contenting.

One of the ways to solve this problem is to use education videos as the education media. Education videos are one of educating aid which has a purpose to interest the students in studying mathematics so that the students are motivated to study mathematics. When they are 
motivated, they will follow the studying process. It is believed to increase their mathematical communication ability.

\section{METHOD}

This research is using quasi experiment method where the researcher took two classes as the research's samples. The first class was the experimental class in which the students got education videos and the second class was the control class in which the students got the usual studying process. Before and after the process, both classes were given a mathematical communication ability parallel test. The populations for this research were the tenth grade students of SMK AL-Halim Garut. This research used a linear program as a material. The class X Multimedia as the experimental class contains of 30 students while class X TKJ as the control class contains of 24 students. The data is collected with giving out tests. The tests were given to both the experimental class and control class. It was done twice, pre-test and post-test. The pre-test was done to identify the students' ability before doing the experiment in both classes and it was done to know whether they had the same ability or not. The posttest was implemented to know the studying efficiency using education videos. It was done after doing the experiment. Both tests were written in essay form. The experiment was used to make sure that the research affected the students' development.

\section{RESULTS AND DISCUSSION}

\section{RESULTS}

From the research by doing the experiment to both classes randomly, a research on class $\mathrm{X}$ Multimedia as the experimental class with 30 students using education videos and class $\mathrm{X}$ $T K J$ as the control class with 24 students using the usual studying process, both given the pretest and post-test, resulted as follows:

Table 1. Pre-test result data

\begin{tabular}{ccc}
\hline & Experimental class & Control class \\
\hline Amount of students & 30 & 24 \\
\hline Highest score & 43 & 39 \\
\hline Lowest score & 20 & 11 \\
\hline Average score & 26.97 & 26.89 \\
\hline Deviation standard & 6.69 & 7.48 \\
\hline
\end{tabular}

1. Pre-test normality experiment

$\mathrm{H}_{0} \quad$ : pre-test samples distribute normally

$\mathrm{H}_{1} \quad$ : pre-test samples do not distribute normally

With the criterion,

If sig. $\geq 0.05$ therefore $\mathrm{H}_{0}$ is accepted.

If sig. $\leq 0.05$ therefore $\mathrm{H}_{0}$ is rejected.

Table 2. Pre-test normality experiment result

\begin{tabular}{cccc}
\hline Class & Sig. & Decision & Conclusion \\
\hline Experimental & 0.012 & $\mathrm{H}_{0}$ rejected & $\begin{array}{c}\text { Did not distribute } \\
\text { normally }\end{array}$ \\
\hline Control & 0.200 & $\mathrm{H}_{0}$ accepted & Distribute normally \\
\hline
\end{tabular}


14 Zakiah, Saomi, Syara, Hidayat, Hendriana. (2018). The Efficiency Of Using Education Videos On The Linear Program Material As Observed In Vocational High School Students' Mathematical Communication Ability. JEE, 1 (1), 11 - 18.

From the table, the experimental class' sig. was $0,012<0,05$ therefore $\mathrm{H}_{0}$ was rejected. It meant that the experimental class did not distribute normally. The control class' sig. was $0,200>0,05$ therefore $\mathrm{H}_{0}$ was accepted. It meant the control class distributed normally. Since one of the classes did not distribute normally, the experiment was continued with nonparametric test which is Mann Whitney's experiment.

2. Mann Whitney's experiment pre-test

$\mathrm{H}_{0} \quad$ : There is no difference on mathematical communication ability efficiency between the students who got education videos and the students who did not get them.

$\mathrm{H}_{1} \quad$ : There is a difference on mathematical communication ability efficiency between the students who got education videos and the students who did not get them.

With the criterion,

If sig. $\geq 0.05$ therefore $\mathrm{H}_{0}$ is accepted.

If sig. $<0.05$ therefore $\mathrm{H}_{0}$ is rejected.

Table 3. Mann Whitney's experiment result

\begin{tabular}{|c|c|c|c|}
\hline \multicolumn{4}{|c|}{ Test Statistics $^{\mathbf{a}}$} \\
\hline & & & $\begin{array}{c}\text { PRETE } \\
\text { ST }\end{array}$ \\
\hline \multicolumn{2}{|l|}{ Mann-Whitney U } & & 354.500 \\
\hline \multicolumn{2}{|l|}{ Wilcoxon W } & & 819.500 \\
\hline \multicolumn{2}{|l|}{$\mathrm{Z}$} & & -.096 \\
\hline \multicolumn{2}{|l|}{ Asymp. Sig. (2-tailed) } & & .923 \\
\hline \multirow{3}{*}{$\begin{array}{l}\text { Monte Carlo Sig. (2- } \\
\text { tailed) }\end{array}$} & Sig. & & $.931^{\mathrm{b}}$ \\
\hline & \multirow[t]{2}{*}{$\begin{array}{l}95 \% \text { Confidence } \\
\text { Interval }\end{array}$} & $\begin{array}{l}\text { Lower } \\
\text { Bound }\end{array}$ & .926 \\
\hline & & $\begin{array}{l}\text { Upper } \\
\text { Bound }\end{array}$ & .935 \\
\hline \multirow{3}{*}{$\begin{array}{l}\text { Monte Carlo Sig. (1- } \\
\text { tailed) }\end{array}$} & Sig. & & $.456^{\mathrm{b}}$ \\
\hline & \multirow[t]{2}{*}{$\begin{array}{l}95 \% \text { Confidence } \\
\text { Interval }\end{array}$} & $\begin{array}{l}\text { Lower } \\
\text { Bound }\end{array}$ & .446 \\
\hline & & $\begin{array}{l}\text { Upper } \\
\text { Bound }\end{array}$ & .466 \\
\hline \multicolumn{4}{|c|}{ a. Grouping Variable: class } \\
\hline \multicolumn{4}{|c|}{ b. Based on 10000 sampled tables with starting seed 2000000 . } \\
\hline
\end{tabular}

Sig. $0,456 \geq 0.05$ therefore $\mathrm{H}_{0}$ is accepted, it meant that "There is no difference on mathematical communication ability efficiency between the students who got education videos and the students who did not get them on a linear program material."

Table 4. Post-test result data

\begin{tabular}{ccc}
\hline & Experiment class & Control class \\
\hline Amount of students & 30 & 24 \\
\hline Highest score & 100 & 93 \\
\hline
\end{tabular}




\begin{tabular}{ccc}
\hline & Experiment class & Control class \\
\hline Lowest score & 66 & 32 \\
\hline Average score & 88.33 & 44.70 \\
\hline Deviation standard & 10.94 & 14.54 \\
\hline
\end{tabular}

1. Post-test normality experiment

$\mathrm{H}_{0} \quad$ : Post-test samples distribute normally

$\mathrm{H}_{1} \quad$ : Post-test samples do not distribute normally

With the criterion,

If sig. $>0.05$ therefore $\mathrm{H}_{0}$ is accepted.

If sig. $<0.05$ therefore $\mathrm{H}_{0}$ is rejected.

Table 5. Post-test normality experiment result

\begin{tabular}{cccc}
\hline Class & Sig. & Decision & Conclusion \\
\hline Experimental & 0.07 & $\mathrm{H}_{0}$ accepted & Distributed normally \\
\hline Control & 0.02 & $\mathrm{H}_{0}$ rejected & $\begin{array}{c}\text { Did not distribute } \\
\text { normally }\end{array}$ \\
\hline
\end{tabular}

From the table above, the experimental class' sig. was $0.07>0.05$ therefore $\mathrm{H}_{0}$ was accepted, it meant that the experimental class distribute normally. The control class' sig. was $0.02<$ 0.05 therefore $\mathrm{H}_{0}$ was rejected, it meant that the control class did not distribute normally. Since one of the classes did not distribute normally, the experiment was continued with nonparametric test which is Mann Whitney's experiment.

2. Mann Whitney's experiment post-test

$\mathrm{H}_{0} \quad$ : The mathematical communication ability efficiency between the students who got education videos and the students who did not get them on linear program material is the same.

$\mathrm{H}_{1} \quad$ : The mathematical communication ability efficiency between the students who got education videos and the students who did not get them on linear program material is more effective on the first group of experiment.

With the criterion,

If sig. $\geq 0.05$ therefore $\mathrm{H}_{0}$ is accepted.

If sig. $\leq 0.05$ therefore $\mathrm{H}_{0}$ is rejected.

Table 6. Mann Whitney's experiment result

\begin{tabular}{lllr}
\hline \multicolumn{2}{c}{ Test Statistics $^{\mathbf{a}}$} & \\
\hline & & \multicolumn{1}{c}{$\begin{array}{c}\text { data } \\
\text { postest }\end{array}$} \\
\hline Mann-Whitney U & & 19.500 \\
\hline Wilcoxon W & & 319.500 \\
\hline $\mathrm{Z}$ & & -5.950 \\
\hline Asymp. Sig. (2-tailed) & & .000 \\
\hline $\begin{array}{l}\text { Monte Carlo Sig. (2- } \\
\text { tailed) }\end{array}$ & Sig. & $.000^{\mathrm{b}}$ \\
\cline { 2 - 4 } & $95 \%$ Confidence & Lower & .000 \\
& Interval & Bound & .000 \\
\cline { 2 - 4 } & & Upper & $.000^{\mathrm{b}}$ \\
\hline $\begin{array}{l}\text { Monte Carlo Sig. (1- } \\
\text { tailed) }\end{array}$ & Sig. & & .000 \\
\cline { 2 - 4 } & $95 \%$ Confidence & Lower & \\
\hline
\end{tabular}


16 Zakiah, Saomi, Syara, Hidayat, Hendriana. (2018). The Efficiency Of Using Education Videos On The Linear Program Material As Observed In Vocational High School Students' Mathematical Communication Ability. JEE, 1 (1), 11 - 18.

\begin{tabular}{llr}
\hline \multicolumn{3}{c}{ Test Statistics $^{\mathbf{a}}$} \\
\hline \multicolumn{2}{c}{ Interval } & $\begin{array}{c}\text { data } \\
\text { postest }\end{array}$ \\
\hline & Bound & .000 \\
\cline { 2 - 3 } & $\begin{array}{c}\text { Upper } \\
\text { Bound }\end{array}$ & \\
\hline a. Grouping Variable: class & & \\
\hline b. Based on 10000 sampled tables with starting seed 299883525. \\
\hline
\end{tabular}

From the table, the sig. was $0.000<0.05$ therefore $\mathrm{H}_{0}$ was rejected, it meant that "The mathematical communication ability efficiency between the students who got education videos and the students who did not get them on linear program material is more effective on the first group of experiment."

\section{DISCUSSION}

Based on the data analysis, the conclusion is matched with the hypotheses. Studying process using education videos is more effective than the usual studying process because in the process the students were obligated to focus on the process so that they were more interested in following it, as observed in the mathematical communication ability of the vocational high school students on a linear program material (Hendriana, Rohaeti, \& Hidayat, 2016; Rahmi, Nadia, Hasibah, \& Hidayat, 2017). The students were also enthusiastic with the new atmosphere in the studying process since SMK AL-Halim Garut is a pesantren* based school whose activities in using technology are limited. Therefore, if the teacher does this innovation, the students will be more enthusiastic to study. It will also help their study results especially in mathematical communication ability.

\section{CONCLUSION}

Based on the data analysis, it can be concluded that "The mathematical communication ability efficiency between the students who got education videos and the students who did not get them on linear program material is more effective on the first group of experiment." This can be seen through the post-test experiment average result. Those who got education videos has bigger average result than those who did not.

\section{REFERENCES}

Febrinal, D. (2016). Peningkatan Kemampuan Komunikasi Matematis Melalui Contextual Teaching Learning (CTL) Di Kelas VIII Smp 44 Sijunjung, Jurnal Kepemimpinan dan Pengurusan Sekolah 1(2). 181-192

Hendriana, H., Rohaeti, E. E., \& Hidayat, W. (2016). Metaphorical Thinking Learning and Junior High School Teachers' Mathematical Questioning Ability. Indonesian Mathematical Society Journal on Mathematics Education, 8(1), 55-64.

Purwanti, B. (2015) Pengembangan Media Video Pembelajaran Matematika dengan Model Assure, Jurnal Kebijakan dan Pengembangan Pendidikan 3(1). $42-47$ 
Putra, Tomi T., Irwan, Vionanda D. (2012). Meningkatkan Kemampuan Berpikir Kreatif Siswa Dengan Pembelajaran Berbasis Masalah, Jurnal Pendidikan Matematika 1(1). $22-26$

Rahmi, S., Nadia, R., Hasibah, B., \& Hidayat, W. (2017). The Relation between Self-Efficacy toward Math with the Math Communication Competence. Infinity Journal, 6(2), 177182.

Ramellan, P., Musdi E., Armiati. (2012). Kemampuan Komunikasi Matematis Dan Pembelajaran Interaktif, Jurnal Pendidikan Matematika 1(1). 77-82

Sundayana, R. (2014). Statistika Penelitian Pendidikan. Garut: STKIP Garut Press.

Yuliana, Tasari, Wijayanti S. (2017). The Effectiveness Of Guided Discovery Learning To Teach Integral Calculus For The Mathematics Students Of Mathematics Education Widya Dharma University. Journal of Mathematics Education, infinity 6(1). 1-10 
18 Zakiah, Saomi, Syara, Hidayat, Hendriana. (2018). The Efficiency Of Using Education Videos On The Linear Program Material As Observed In Vocational High School Students' Mathematical Communication Ability. JEE, 1 (1), 11 - 18. 